\title{
Assessing Shariah Disclosure in Pakistan: The Case of Islamic Banks
}

\author{
Muhammad Ismail ${ }^{1}$, Shafiullah Jan², Karim Ullah ${ }^{3}$
}

\begin{abstract}
The foundation of Islamic banking and finance is based on the Islamic law of business transactions/ muamlat, which also confines to the moral and ethical codes of Islam. Also, the involvement of Shariah and Islamic ethics in the governance structure of Islamic banks gives rise to a special kind of disclosure issue called Shariah disclosure. The literature suggests, that stakeholders, including customers and shareholders, use Shariah disclose as core criteria to direct their transactions with Islamic Banking Institutions (IBIs). However, the available disclosure indices in the established literature are not insufficient for assessing Shariah disclosure of the IBIs. The present research study attempts to assess the level of Shariah disclosure of five fullfledged Islamic banks in Pakistan. For this purpose, the study developed Shariah Disclosure Index (ShDI). ShDI will be used as the basis upon the disclosure requirements of State Bank of Pakistan (SBP), Accounting and Auditing Organizations for Islamic Financial Institutions (AAOIFI), and Islamic business reporting literature. A survey design is used to collect the data for ShDI constructs by utilizing annual reports of the five full-fledged banks from the year of 2015 until 2017. The findings disclosed that the Shariah disclosure in Pakistani Islamic banks is satisfactory i.e., near 70\% compared 30\% Shariah disclosure of the foreign Islamic banks operating in Pakistan. It is appreciable that all the Islamic banks, particularly Pakistani Islamic banks, disclosing about 80\%-90\% of the SBP mandatory and AAOIFI recommended Shariah disclosure items. While, disclosure of the voluntary Shariah disclosure items are still very low i.e. $15 \%$. It is also noted that the Shariah disclosure level was gradually improving which portrays in the increment of the average Shariah disclosure level in 2017 compared to 2015. The research provides a benchmark and indicator for all stakeholders who are making their investment and business decisions In addition, the study is equally important for IBIs to comply with ShDI to ensure full Shariah disclosure in order to attract new investors, religiously excluded investors, and protect the ideological stance and religious commitments of the existing customers as well.
\end{abstract}

Keywords: Islamic banking, Islamic financial inclusion, Shariah Disclosure Index (ShDI), Shariah governance, Shariah report.

1 PhD Scholar, Islamic Business $\mathcal{G}$ Finance, Institute of Management Sciences, Peshawar.

Email:muhammadismailrashid@gmail.com

2 Assistant Professor, Institute of Management Sciences, Peshawar. Email: shafiullah.jan@imsciences.edu.pk

3 Assistant Professor, Institute of Management Sciences, Peshawar. Email: karim.ullah@imsciences.edu.pk

\begin{tabular}{ll} 
ARTICLE HISTORY & \\
30 Aug, 2019 Submission Received & 24 Feb, 2020 First Review \\
\hline 27 Feb, 2020 Second Review & 19 Mar, 2020 Third Review \\
\hline
\end{tabular}

03 Apr, 2020 Accepted 


\section{Introduction}

Islamic banking and finance is a unique kind of banking phenomenon, which is purely based on the Islamic law of business transactions/muamlat (Jan \& Asutay, 2019). Islamic banking is also known as ethical banking as it also stands on the Islamic business ethical values. Furthermore, the involvement of Shariah in the banking operations, activities, governance, investment, and products and services designing give rise to a special kind of disclosure issue called Shariah disclosure. Thus, it is not the additional, but fundamental responsibility of the Islamic banks to ensure full disclosure and transparency of their internal governance environment and compliance with Shariah. Many scholars argued that to protect their ideological stance and religious commitments, Muslims customers are very keen to know the Islamicity of the Islamic banks' operations, activities, governance, investment, and products and services designing (Gilani, 2015; Grais \& Pellegrini, 2006; Al-Mehmadi, 2004). Normally, the existing customers select their investment and business decisions provided by Islamic banking institutions based on Shariah disclosure. Therefore, Shariah disclosure is very essential not only for the existing Muslims customers but also for other potential customers across the world including non-Muslims.

The present research study attempts to assess the level of Shariah reporting and disclosure in Pakistan's five full-fledged Islamic banks. To meet the objective of the study the study first developed a Shariah Disclosure Index (ShDI) by considering the Shariah reporting requirements of State Bank of Pakistan (SBP) Shariah governance framework-2018, AAOIFI, and others Islamic reporting literature. The sample size of the study is Pakistan's five full-fledged Islamic banks. Their annual reports analyzed over the period 2015-2017. Survey design is used to achieve the objectives of the study. The research provide a benchmark for the Islamic bank's stakeholders in making their investment and business decisions based on Shariah reporting and disclosure.

\subsection{Significance of the research}

The current research is a first study of its kind, which is primarily focusing on the Shariah reporting and disclosure in Pakistan's Islamic banking institutions. The study also is an attempt to provide a benchmark for Islamic reporting to Pakistan's Islamic banking institutions. By constructing ShDI, the study primarily focus on the existing regulatory disclosure requirements, AAOIFI disclosure requirements, and other disclosure items as discussed in the pertinent literature. The study will contribute to the existing literature of Shariah reporting in Islamic banking and finance especially in Pakistan's perspective. This study also help in designing optimal policies on Shariah reporting and disclosure for Pakistan's Islamic banking and finance industry. Furthermore, the research will provide a benchmark and indicator for all concern 
and potential stakeholders who are making their investment and business decisions based on the Islamic banks' Shariah reporting and disclosure. Besides, this study also provides important concern on the inclusion of the financial investors, who are excluded because of their difference ideological stance and commitment to Shariah.

\subsection{Research gap}

The literature available related to the Islamic corporate governance principles and disclosure covered a lot about financial, governance, and corporate statements disclosure. While, little literature is available related to the Shariah disclosure framework in IBIs. Furthermore, so far in Pakistan, there is no study exist for assessing the Shariah reporting and disclosure in IBIs. Therefore, the present study is an attempt to fill this gap through developing ShDI by considering the existing regulatory disclosure requirements, AAOIFI disclosure requirements, and volunteer disclosure items explored in the prior pertinent literature.

\section{Literature Review}

According to Grassa (2013), Shariah governs all aspects of the IBIs' which adds additional values to the existing corporate governance (CG) structure Islamic banks. Therefore, Shariah generated special kinds of corporate governance challenges in the Isalmic banks. The involvement of Shariah experts in the CG activities of an Islamic bank gives rise to some unique issues, such as, independency, confidentiality, competency, consistency, and disclosure (Grais \& Pellegrini, 2006; Zainuddin \& Nordin, 2016; Hasan, 2011). While, Hamid, Ubud, Djumahir, \& Siti (2016) and Grassa (2013) added transparency and reputation, respectively, in the list of issues that arise due to the engagement of Shariah advisors in the Islamic bank's corporate governance system.. Shariah reporting and disclosure refers to the communication of Shariah information to all the concern stakeholders. Gilani (2015) argued that Islamic business ethical values are the salient features of the Islamic financing modes that attract the financial stakeholders. Stakeholders, whether existing or potential, usually rely on the Islamic bans' annual reports while making their decisions on investment or any other sort of financial decisions (Othman, Thani, \& Ghani, 2009). This prove that to protect their ideological stance and religious commitments, Muslims customers are very keen to know the Islamicity of the Islamic banks' operations, activities, governance, investment, and products and services designing (Jan, Khan \& Ullah, 2018; Jan, Ullah \& Asutay, 2015; Jan, Ullah \& Asutay, 2016).

Raharja (2011) also argued that IFIs must comply with the Shariah in all condition. Therefore, there is an existence of high demand on the Shariah compliance to ensure full disclosure for all banking activities, operations, products, and services. 
The involvement of Shariah in the corporate governance arrangement of Islamic banks gives rise to a special kind of disclosure issue called Shariah disclosure and reporting (Grassa, 2013; Grais \& Pellegrini, 2006; Hasan, 2012; Srairi, 2015; Askari, Iqbal, Krichenne, \& Mirakhor, 2010). Disclosing information, concern to Islamic products and services, attract the potential investors who are conscious about the Islamicity of bank's activity (Grassa, Chakroun, \& Hussainey, 2018). It means that Islamicity and Islamic ethical identity is the fundamental determinants which make Islamic banking become the first choice of Muslims investors. Therefore, higher Shariah reporting and disclosure strengthen the confidence of both the existing and potential investors in IBIs.

Ismail, Jan, \& Ullah (2018) established a detailed study on the Shariah attributes that should be disclosed in the annual reports of Islamic banks. Their inquiry is very comprehensive in the sense that it covers three important dimensions of the Shariah disclosure framework i.e. Shariah disclosure information, mechanisms of Shariah disclosure, and adaptability in Shariah disclosure. Regarding disclosure of Shariah information in the annual report of IFIs, the authors recommended that institutions shall disclosed about their investment avenues along with proof of Islamicity, Shariah appraisal of the developed products and services, and showing Shariah compliance through actions. Said, Abd Samad, Mohd Sidek, Ilias and Omar (2018) constructed Maqasid index, based on disclosure analysis, for evaluated the performance of Islamic banks. They access Islamic banks based on the disclosure of Islamic banks' contributions toward the objectives of Shariah. Maali, Casson, \& Napier (2006) emphasized on the disclosure of IFIs' justly dealing with their employees, customers, and all other stakeholders. Sugianto \& Harapan (2017) suggested that IFI shall disclose details of their charities given to the poor and needy people. Zubairu, Sakariyau, \& Dauda (2012) explored an important attribute that an IFI's shall disclose in their annual report and that is the disclosure of an institution's commitment toward its debtor.

In the established Shariah governance disclosure literature, there are different indexes developed for evaluating the Islamic business ethical and Shariah reporting of IBIs. Abdullah, Percy, \& Stewart (2015) developed Voluntary Corporate Governance Disclosures Index (VCGDI) for evaluating reporting level in southeast Asian and GCC Islamic banks; Albassam \& Ntim (2017) developed IslamicValues Disclosure Index (IVDI) for measuring the level of Islamic reporting in Saudi's Shariah compliant companies; Inten \& Devi (2017) constructed Islamic Social Reporting Index (ISRI) for valuating Islamic social reporting in Indonesian and Malaysian Islamic banks; Masruki, Hanefah, \& Wahab (2018) developed Shariah Subervisory Board Index (SSBI) for measuring the level of Shariah supervisory board related information in Malaysian Islamic banks; Noordin, Kassim, Prabangasta, \& Hayeeyahya (2015) developed Shariah 
governance Disclosure Index (SDI) for measuring the level of Shariah governance reporting in Malaysian Islamic banks; Ousama \& Fatima (2010) constructed Islamic Disclosure Index (IDI) for assessing the level of Islamic reporting in Shariah approved companies listed on Bursa Malaysia; Abdullah, Percy, \& Stewart (2013) developed Shariah Supervisory Board Index (SSB Index) for measuring Shariah reporting in Malaysian and Indonesian Islamic banks; El-halaby, Hussainey, \& El-Sood (2015) developed SSB Disclosure Index for measuring Shariah compliance in 23 Islamic banks globally; Haniffa \& Hudaib (2007) constructed Ethical Identity Index (EII) for measuring ethical reporting in Malaysian and Indonesian Islamic banks; Asutay \& Harningtyas (2015) developed Maqasid al-Shariah Index for valuating Maqasid al-Shariah through Islamic banks' activities.

\section{Methodology of the Research}

\subsection{Type of research and research design}

The research is applied in nature in which the purpose is to assess the level of Shariah disclosure and reporting in Pakistan's full-fledged Islamic banks. Research design is based on the nature of the data collection technique. Primarily, survey design used in this study in which items of the self-constructed index were investigated in the sample Islamic banks' annual reports. Therefore, based on the established evidences,, survey design is an ideal and the most appropriate method for indexation and comparing studies (Belal, Abdelsalam, \& Nizamee, 2015; Blancone, Shakhatreh, \& Radwan, 2016; Hassan \& Syafri Harahap, 2010). In this study all five full-fledged Islamic banks, listed on SBP website, are used for data collection. Total 27 reports, including both annual reports and Shariah reports, were analyzed over the period of 2015-2017. ShDI will be constructed based on the SBP's Shariah governance framework-2018, AAOIFI disclosure requirements, and some prior Islamic reporting literature.

\subsection{Data collection and information}

The secondary data will be collected from the annual reports of Pakistan's full fledge Islamic banks. Currently, there are five full fledge Islamic banks in Pakistan namely Meezan Bank Limited (MEBL), Bank Islami Pakistan Limited (BIPL), Dubai Islamic Bank Limited (DIBL), Al-Barakah Bank Pakistan Limited (ABPL), and MCB Islamic Bank Limited (MIBL). Three years data, both financial report and Shariah report, collected over a period 2015-2017. The reason is that MIB is comparatively a new bank which is established in 2015 and their annual reports are available from 2015. Both the financial reports and Shariah reports of these Islamic banks are available on their respective websites. Therefore, these websites are approached for data collection. 
Table 1: List of Annual Reports Collected from Pakistan's Full-fledged Islamic Banks' Websites.

\begin{tabular}{|c|c|c|c|c|}
\hline Name of the Islamic Bank & 2015 & 2016 & 2017 & Total \\
\hline Meezan Bank Limited & $\mathrm{FR}^{*}+\mathrm{SR} * *$ & $\mathrm{FR}+\mathrm{SR}$ & $\mathrm{FR}+\mathrm{SR}$ & 6 \\
\hline Bank Islami & $\mathrm{FR}+\mathrm{SR}$ & $\mathrm{FR}+\mathrm{SR}$ & $\mathrm{FR}+\mathrm{SR}$ & 6 \\
\hline Dubai Islamic Bank Pakistan & $\mathrm{FR}$ & $\mathrm{FR}$ & $\mathrm{FR}+\mathrm{SR}$ & 4 \\
\hline Albaraka Bank Pakistan & $\mathrm{FR}+\mathrm{SR}$ & $\mathrm{FR}+\mathrm{SR}$ & $\mathrm{FR}+\mathrm{SR}$ & 6 \\
\hline MCB Islamic Bank & $\mathrm{SR}$ & $\mathrm{FR}+\mathrm{SR}$ & $\mathrm{FR}+\mathrm{SR}$ & 5 \\
\hline \multicolumn{4}{|r}{ Total Reports } & 27 \\
\hline
\end{tabular}

*FR - Financial Report, ** SR - Shariah Report

\subsection{Data analysis}

The data collected from the annual reports analyzed by using disclosure analysis approach in which ShDI items were investigated. Disclosure analysis approach is an ideal approach when the study aims to investigate for items in documents (Platonova, 2014; Zafar \& Sulaiman, 2018; Ahmed \& El-belihy, 2017)already on the ethical banking horizon, the Islamic banking model (in theoryalready on the ethical banking horizon, the Islamic banking model (in theoryalready on the ethical banking horizon, the Islamic banking model (in theory. . For scoring the index themes, binary or dichotomous value approach were adopted which is frequently followed in the prior similar studies (Albassam \& Ntim, 2017; Triyuwono \& Kamayanti, 2014; Harun, 2016annual reports of GCC Islamic banks for the period 2010- 2014 are analysed using manual content analysis, which involves 195 observations of 39 Islamic banks. The CSR disclosure index is constructed based on 11 dimensions using AAOIFI standard no 7, 2010. An ordinary least square (OLS; Rahman, Danbatta, \& Saimi, 2014; Ibrahim, Wirman, Alrazi, \& Pramono, 2004; Haniffa \& Hudaib, 2007; Darmadi, 2013; Abdullah et al., 2015). According to the approach, if an Islamic bank disclosing a particular theme, in their annual report, so it will score 1 otherwise 0 , if not disclosing. Furthermore, the following formula for calculating ShDI is inspired from the work of Haniffa \& Hudaib (2007); Ibrahim et al. (2004); and Kamla \& Rammal (2013). ShDI for a bank calculated as:

$$
\begin{aligned}
& \text { ShDI }=\frac{\sum A D T}{\mathrm{~N}^{\text {th }} \mathrm{EDT}} \times 100 \\
& \text { Where } \\
& \sum \mathrm{ADT}=\text { Sum of actual disclosed themes } \\
& \mathrm{N}^{\text {th }} \mathrm{EDT}=\text { Total number of expected disclosure themes }
\end{aligned}
$$


Higher the ShDI value represents best Shariah disclosure and reporting practices and vice-versa.

\section{Developing Shariah Disclosure Index (ShDI)}

ShDI is a specific kind of index developed to compare the expected disclosure items with the actual Islamic banks' Shariah disclosure practices. indexation is a process in which the developer compared designed models with real system parameters (Ullah, 2014). In addition to it, it is also the Shariah responsibility of the Islamic banks to ensure full disclosure especially Islamicity disclosure (Abdullah \& Syariati, 2016; Herwiyanti, MA, \& Rosada, 2005; Obid \& Hajj, 2011). Therefore, to ensure full Shariah disclosure, the present study is an attempt to develop a comprehensive and adequate index for evaluating the Shariah disclosure level of Islamic banks. ShDI were constructed by following the below fundamental steps.

Step-I: Reviewing of prior literature on Shariah and Islamic corporate governance indexation. These literatures include SPB's Shariah governance framework-2018, original and high quality journal papers regarding Shariah disclosure, and AAOIFI's governance standards.

Step-II: Key Shariah disclosure themes were identified from the prior literature and then categorized it in three different sets. According to Raharja (2011) in accounting and financial system, there are three broad categories of disclosure, mandatory, recommended and voluntary. In present study, mandatory disclosure refers to the native regulator(s), recommended disclosure refers to the standards or guidelines by the international standard setting agencies, and the voluntary disclosure refers to the recommendations of the prior original studies. The themes are categorized based on SBP's mandatory themes, AAOIFI's recommended themes, and prior studies' voluntary disclosure themes. There are total 53 themes in which 27 were extracted from SBP-Shariah governance framework-2018, 6 from AAOIFI's governance standards, and 20 from prior studies.

Step-III: Coding of themes is the third step of ShDI development. In this step themes were coded based on their respective class and number. SBP's mandatory themes represented by SSDR which means SBP's SGF Disclosure Requirements, AAOIFI's recommended themes represented as ASDR which refers to AAOIFI's Shariah Disclosure Requirements, and themes extracted from prior studies were symbolized as VSDI which means Voluntary Shariah Disclosure Items. All the extracted themes and their respective codes are mentioned in the following Table: 2, Table: 3, and Table: 4 .

Step-IV: In fourth step, themes of each set were scored based on dichotomous or binary value system approach. According to this approach, each theme scored by $0-1$ 
or $0-0.75$ or $0-0.5$. If the SSDR's theme disclosed in the bank annual report so it will score 1 otherwise 0 . In the same way, if a particular ASDR theme disclosed in the bank annual report so it will score 0.75 otherwise 0 . Similarly, if the bank disclosed a particular VSDI's theme in their annual report so it will score 0.5 otherwise 0 . The score of the entire 53 themes is 41.5 .

Step-V: Calculation of ShDI or indexation for each Islamic bank is the fifth step of ShDI. In this step the achieved score of each Islamic bank is multiplied with 100 and then divided by the ideal desired score of ShDI which is 41.5. The final value is the ShDI score in term of percentage. Higher the ShDI value indicates higher Shariah disclosure in the particular Islamic bank while lower the ShDI value indicates lower Shariah disclosure.

Table 2: Themes Extracted from IBD-SBP's Shariah Governance Framework-2018.

\begin{tabular}{|c|c|c|c|}
\hline No & Theme's Code & Description of Theme & Theme's Score \\
\hline 1 & $\mathrm{SSDR}^{*}-1$ & $\begin{array}{l}\text { The bank's annual Shariah report published in English } \\
\text { in its annual report. }\end{array}$ & $0-1$ \\
\hline 2 & SSDR-2 & $\begin{array}{l}\text { The bank's annual Shariah report published in Urdu in } \\
\text { its annual report. }\end{array}$ & $0-1$ \\
\hline 3 & SSDR-3 & $\begin{array}{l}\text { Opening of annual Shariah report with the name of } \\
\text { Allah }\end{array}$ & $0-1$ \\
\hline 4 & SSDR-4 & $\begin{array}{l}\text { Statement that the "Board of Directors and Executive } \\
\text { Management are solely responsible to ensure that the } \\
\text { operations of the bank are conducted in a manner } \\
\text { that comply with Shariah principles at all times, we } \\
\text { are required to submit a report on the overall Shariah } \\
\text { compliance environment of the bank" }\end{array}$ & $0-1$ \\
\hline 5 & SSDR-5 & $\begin{array}{l}\text { There is an effective mechanism for BODs to frequently } \\
\text { oversight the Shariah compliance mechanism of the } \\
\text { bank }\end{array}$ & $0-1$ \\
\hline 6 & SSDR-6 & $\begin{array}{l}\text { The bank has established an independent and effective } \\
\text { SSB and the SBP's Fit and Proper Criteria (FAPC) } \\
\text { properly adopted in the appointment of SSB's mem- } \\
\text { bers. }\end{array}$ & $0-1$ \\
\hline 7 & SSDR-7 & $\begin{array}{l}\text { The bank has at least three Shariah advisors in their } \\
\text { SSB. }\end{array}$ & $0-1$ \\
\hline 8 & SSDR-8 & $\begin{array}{l}\text { The bank has Resident Shariah Board Member (RSBM) } \\
\text { to frequently oversee the Shariah compliant status of } \\
\text { bank's products, services, and operations. }\end{array}$ & $0-1$ \\
\hline
\end{tabular}




\begin{tabular}{|c|c|c|c|}
\hline 9 & SSDR-9 & $\begin{array}{c}\text { To assist SSB, the bank has an effective Shariah Compli- } \\
\text { ance Department (SCD) which also serve as a conduit } \\
\text { between SSB and bank's management }\end{array}$ & $0-1$ \\
\hline 10 & SSDR-10 & $\begin{array}{l}\text { Reporting concerning SCD's verification and approval } \\
\text { of the distribution of profit and loss sharing mecha- } \\
\text { nism with depositors, prior to its disbursement in the } \\
\text { concern depositors. }\end{array}$ & $0-1$ \\
\hline 11 & SSDR-11 & $\begin{array}{l}\text { Disclosure of the avenues and their Shariah conformity } \\
\text { wherein the bank deploy of funds of investors especially } \\
\text { IAHs. }\end{array}$ & $0-1$ \\
\hline 12 & SSDR-12 & $\begin{array}{l}\text { The BOD meted the SSB at least twice a year regarding } \\
\text { strengthen the bank Shariah compliance environment } \\
\text { and enforcement of SSB's pronouncements. }\end{array}$ & $0-1$ \\
\hline 13 & SSDR-13 & $\begin{array}{l}\text { The bank frequently arranges trainings and learning } \\
\text { seminar concerning Islamic finance for their manage- } \\
\text { ment. }\end{array}$ & $0-1$ \\
\hline 14 & SSDR-14 & The SSB meted at least on a quarterly basis. & $0-1$ \\
\hline 15 & SSDR-15 & $\begin{array}{l}\text { The bank's SCD conducted Shariah reviews, on test } \\
\text { check basis, of each class of transactions, the relevant } \\
\text { documentation and process flows. }\end{array}$ & $0-1$ \\
\hline 16 & SSDR-16 & The bank conducted internal Shariah audit. & $0-1$ \\
\hline 17 & SSDR-17 & The bank conducted external Shariah audit. & $0-1$ \\
\hline 18 & SSDR-18 & $\begin{array}{l}\text { SSB's opinions concerning bank's Shariah the com- } \\
\text { pliance environment of the bank in the light of SSB's } \\
\text { issued fatwah }\end{array}$ & $0-1$ \\
\hline 19 & SSDR-19 & $\begin{array}{l}\text { SSB's opinions that whether or not the bank's prod- } \\
\text { ucts, services, and operations are in accordance with the } \\
\text { SBP-IBD's directives, rulings of SBP's Shariah Board's, } \\
\text { and SBP's Shariah governance framework. }\end{array}$ & $0-1$ \\
\hline 20 & SSDR-20 & $\begin{array}{c}\text { Reporting concerning "SSB's opinions that whether or } \\
\text { not the bank has a comprehensive mechanism in place } \\
\text { to ensure Shariah compliance in their overall opera- } \\
\text { tions" }\end{array}$ & $0-1$ \\
\hline 21 & SSDR-21 & $\begin{array}{l}\text { The bank's earnings realized from sources or by means } \\
\text { prohibited by Shariah have been credited to charity } \\
\text { account }\end{array}$ & $0-1$ \\
\hline 22 & SSDR-22 & Charity fund are being properly utilized. & $0-1$ \\
\hline 23 & SSDR-23 & $\begin{array}{l}\text { Disclosure of the SSB's opinions that whether or not } \\
\text { the bank efficiently followed the SBP instructions } \\
\text { concerning profit and loss distribution, before disburse- } \\
\text { ment, and pool management. }\end{array}$ & $0-1$ \\
\hline
\end{tabular}




\begin{tabular}{|c|c|c|c|}
\hline 24 & SSDR-24 & $\begin{array}{c}\text { Disclosure concerning the level bank's management } \\
\text { awareness toward Islamic finance and acknowledging } \\
\text { their sincerity and efforts in the promotion of Islamic } \\
\text { banking }\end{array}$ & 0-1 \\
\hline 25 & SSDR-25 & $\begin{array}{c}\text { SSB opinions concerning that whether or not SSB } \\
\text { facilitated and well-informed while discharging their } \\
\text { duty effectively. }\end{array}$ & $0-1$ \\
\hline 26 & SSDR-26 & Report of the outstanding Shariah related issues. & $0-1$ \\
\hline 27 & SSDR-27 & Signatures of the entire SSB's members on the annual \\
Shariah report. & $0-1$ \\
\hline
\end{tabular}

* SSDR - SBP's SGF Disclosure Requirements

Table 3: Themes Extracted from AAOIFI's Governance Standards.

\begin{tabular}{|c|c|c|c|}
\hline No & Theme's Code & Description of Theme & Theme's Score \\
\hline 28 & ASDR ${ }^{* *}-1$ & $\begin{array}{c}\text { Disclosure of fatawa/ Shariah pronouncements guide- } \\
\text { lines of the SSB. }\end{array}$ & $0-0.75$ \\
\hline 29 & ASDR-2 & A proper title of bank's SSB report & $0-0.75$ \\
\hline 30 & ASDR-3 & $\begin{array}{c}\text { The calculation of Zakat is in compliance with the } \\
\text { Shariah rules and principles }\end{array}$ & $0-0.75$ \\
\hline 31 & ASDR-4 & The bank has clear policy for waqf management & $0-0.75$ \\
\hline 32 & ASDR-5 & $\begin{array}{c}\text { Greetings the addressee by Assalamu Alaykum Wa } \\
\text { Rahmatu Allah Wa Barakatuh }\end{array}$ & $0-0.75$ \\
\hline 33 & ASDR-6 & $\begin{array}{c}\text { Closing the Shariah report by Wassalamu Alaykum Wa } \\
\text { Rahmatu Allah Wa Barakatuh }\end{array}$ & $0-0.75$ \\
\hline
\end{tabular}

** ASDR - AAOIFI's Shariah Disclosure Requirements

Table 4: Voluntary Shariah Disclosure Themes Extracted from Prior Research Studies.

\begin{tabular}{|c|c|c|c|c|}
\hline No & $\begin{array}{c}\text { Theme's } \\
\text { Code }\end{array}$ & Description of Theme & $\begin{array}{c}\text { Theme's } \\
\text { Score }\end{array}$ & Reference \\
\hline 34 & VSDI***-1 $^{* *}$ & Amount subject to Zakat & $0-0.50$ & $\begin{array}{c}\text { Abdullah et } \\
\text { al. (2013) }\end{array}$ \\
\hline 35 & VSDI-2 & Zakat beneficiaries & $0-0.50$ & $\begin{array}{c}\text { Abdullah et } \\
\text { al. (2013) }\end{array}$ \\
\hline 36 & VSDI-3 & $\begin{array}{c}\text { There is a robust Shariah non-compliance risk } \\
\text { management framework in the bank. }\end{array}$ & $0-0.50$ & $\begin{array}{c}\text { Abdullah } \\
\text { (2014) }\end{array}$ \\
\hline
\end{tabular}




\begin{tabular}{|c|c|c|c|c|}
\hline 37 & VSDI-4 & $\begin{array}{l}\text { Statement concerning "bank's financing } \\
\text { strategies includes formal exclusions of any } \\
\text { engagement that deals with haram or unlawful } \\
\text { goods and services" }\end{array}$ & $0-0.50$ & $\begin{array}{l}\text { Abdullah } \\
\text { (2014) }\end{array}$ \\
\hline 38 & VSDI-5 & The bank disclose Qard Al-Hassan statement & $0-0.50$ & $\begin{array}{c}\text { Abuhmaira } \\
\text { (2006) }\end{array}$ \\
\hline 39 & VSDI-6 & $\begin{array}{l}\text { The bank debt written off policy for insolvent } \\
\text { debtors. }\end{array}$ & $0-0.50$ & $\begin{array}{l}\text { Ahmed \& } \\
\text { El-belihy } \\
(2017)\end{array}$ \\
\hline 40 & VSDI-7 & Definition of the Islamic products offered & $0-0.50$ & $\begin{array}{l}\text { Al-baluchi } \\
\text { (2006) }\end{array}$ \\
\hline 41 & VSDI-8 & Shariah screening during investment. & $0-0.50$ & $\begin{array}{l}\text { Amran et al. } \\
\text { (2017) }\end{array}$ \\
\hline 42 & VSDI-9 & The bank Shariah examination procedures. & $0-0.50$ & $\begin{array}{l}\text { Darmadi } \\
(2013)\end{array}$ \\
\hline 43 & VSDI-10 & $\begin{array}{l}\text { The bank disclosed experience of SSB's } \\
\text { members }\end{array}$ & $0-0.50$ & $\begin{array}{l}\text { Elamer, } \\
\text { Ntim, \& Ab- } \\
\text { dou (2017) }\end{array}$ \\
\hline 44 & VSDI-11 & $\begin{array}{l}\text { Is the report shows that the bank comply with } \\
\text { the AAOIFI's Shariah standards }\end{array}$ & $0-0.50$ & $\begin{array}{l}\text { El-halaby et } \\
\text { al. (2015) }\end{array}$ \\
\hline 45 & VSDI-12 & $\begin{array}{l}\text { The bank future directions in serving the } \\
\text { needs of Muslim community }\end{array}$ & $0-0.50$ & $\begin{array}{l}\text { Haniffa } \\
\text { \& Hudaib } \\
(2007)\end{array}$ \\
\hline 46 & VSDI-13 & $\begin{array}{l}\text { The bank involvement in non-permissible } \\
\text { activities-\% of profit }\end{array}$ & $0-0.50$ & $\begin{array}{l}\text { Haniffa } \\
\text { \& Hudaib } \\
\text { (2007) }\end{array}$ \\
\hline 47 & VSDI-14 & SSB's approval for new products and services & $0-0.50$ & $\begin{array}{l}\text { Obid \& Hajj } \\
\quad(2011)\end{array}$ \\
\hline 48 & VSDI-15 & The bank policy on Late Repayments & $0-0.50$ & $\begin{array}{l}\text { Othman \& } \\
\text { Thani (2010) }\end{array}$ \\
\hline 49 & VSDI-16 & $\begin{array}{l}\text { BOD and top management knowledge and } \\
\text { competence in banking and Shariah }\end{array}$ & $0-0.50$ & $\begin{array}{c}\text { Rashid \& } \\
\text { Hassan } \\
(2014)\end{array}$ \\
\hline 50 & VSDI-17 & The bank just dealings with its employees. & $0-0.50$ & $\begin{array}{l}\text { Maali, } \\
\text { Casson, } \\
\text { \& Napier } \\
\text { (2006) }\end{array}$ \\
\hline 51 & VSDI-18 & $\begin{array}{l}\text { The bank has a formal policy on duties and } \\
\text { responsibilities of SSB. }\end{array}$ & $0-0.50$ & Srairi (2015) \\
\hline
\end{tabular}




\begin{tabular}{|c|c|c|c|c|}
\hline 52 & VSDI-19 & Remuneration of SSB & $0-0.50$ & $\begin{array}{c}\text { Setyawan \& } \\
\text { Permatasari } \\
(2017)\end{array}$ \\
\hline 53 & VSDI-20 & $\begin{array}{c}\text { The bank disclosure toward maqasid al } \\
\text { Shariah }\end{array}$ & $0-0.50$ & $\begin{array}{c}\text { Said et al. } \\
(2018)\end{array}$ \\
\hline
\end{tabular}

*** VSDI - Voluntary Shariah Disclosure Items

\section{Findings and Discussion}

Besides other disclosure arrangement, Islamic banks need to ensure adequate Shariah reporting and disclosure. The established literature suggested different Shariah reporting and disclosure attributes in which the Islamic banks' stakeholders are interested. These attributes includes SSB related disclosure, disclosure about investment avenues and their proof of Islamicity, Islamicity of the products and services, disclosure of the Shariah pronouncements, disclosure of the bank annual Shariah report, disclosure of the bank annual Shariah audit report, and disclosure of bank charity account details, etc. Therefore, based on all these attributed, we developed a disclosure index called Shariah disclosure index (ShDI) and then evaluated the Shariah disclosure practices of the Pakistani full-fledged Islamic banks by using their annual report for the years 2015-2017. The result shows that the overall Shariah disclosure levels for the five full-fledged Islamic banks in Pakistan are 53.74\%. However, the level of Shariah disclosure in Pakistani Islamic banks and foreign Islamic banks are 69\% and 30.35\% respectively, which shows that Pakistani Islamic banks are the more satisfactory in term of Shariah disclosure and reporting. In addition to it, bank wise Shariah disclosure, Bank Islami is on top by securing score of $75 \%$ followed by MEBL, MIBL, ABPL, and DIBL by securing score of 71\%, 62\%, 39\%, and $23 \%$ respectively. In addition, Islamic banks disclosed about $80 \%-90 \%$ of the SSDR and ASDR themes, whereas, on the other hand, these banks disclose very low percentage of VSDI themes. Furthermore, it is also noticed that Shariah disclosure level is improving with time in all Islamic banks except in BIPL which remain the same throughout 2015-2017. The findings are summarized in the Table: 5 given below.

\section{Conclusion}

The results show that Islamic banks in Pakistan have low level of Shariah disclosure. It is observable that Islamic banks do not disclose adequate Shariah information related to the activities that may attract criticism, such as the Shariah appraisal of ambiguous transactions. On the other hand, they did provide more disclosures regarding their charitable activities and their involvement in social upbringing of the society. The scope of the study is limited to disclosure of Shariah information and the Islamicity evidence of products, services, operations, and activities. Therefore, other 
Table 5: Summarized Table Showing Shariah Disclosure in Pakistan's Full-fledged Islamic Banks.

\begin{tabular}{|c|c|c|c|c|c|c|c|}
\hline Rank & $\begin{array}{l}\text { Name of the } \\
\text { Islamic Bank }\end{array}$ & ShDI2015 & ShDI2016 & ShDI2017 & ShDIA $^{*}$ & $\begin{array}{l}\text { Pakistani } \\
\text { vs Foreign }\end{array}$ & ShDIC** \\
\hline 1 & Bank Islami & $75 \%$ & $75 \%$ & $75 \%$ & $75 \%$ & \multirow[t]{3}{*}{$69 \%$} & \multirow[t]{5}{*}{$53.74 \%$} \\
\hline 2 & Meezan Bank & $68 \%$ & $70.5 \%$ & $74.7 \%$ & $71 \%$ & & \\
\hline 3 & $\begin{array}{c}\text { MCB Islamic } \\
\text { Bank }\end{array}$ & $48.8 \%$ & $66.8 \%$ & $70.5 \%$ & $62 \%$ & & \\
\hline 4 & Al Baraka Bank & $38 \%$ & $38 \%$ & $40.4 \%$ & $39 \%$ & \multirow[t]{2}{*}{$30.35 \%$} & \\
\hline 5 & $\begin{array}{c}\text { Dubai Islamic } \\
\text { Bank }\end{array}$ & 0 & 0 & $65.7 \%$ & $23 \%$ & & \\
\hline
\end{tabular}

${ }^{*}$ ShDIA - Average ShDI, **ShDIC - Cumulative ShDI

type of disclosure such as social disclosure, corporate disclosure, ethical disclosure, moral disclosure, cultural and environmental disclosure may not be discussed in this study. This limitation become the opportunity for the Future study and other improvement can be made by including the Shariah disclosure requirements of Islamic Fiqh Academy Jeddah, Islamic Financial Services Board (IFSB), Securities and Exchange Commission of Pakistan (SECP), and fatwa giving department/ Darul Ifta of Pakistan's prominent religious institutions like Darul Uloom Karachi, Jamia tur Rasheed Karachi, Shariah Academy - IIU Islamabad, etc. Furthermore, this study has ranked Islamic banks on the basis of their Shariah disclosure only without taking into considerations of other elements such as the bank assets, branches, time, business, market shares, bank management, technological advancement, etc.

The research provided a benchmark and indicator for all concern and potential stakeholders who are making their investment and business decisions based on the Islamic banks' Shariah disclosure. In addition to it, the study is equally important for IBIs to comply with ShDI and ensure full Shariah disclosure for attracting new investors and protect their ideological and religious commitments as well. Furthermore, to keep the confidence of stakeholders in Islamic banks, it is recommended to IBIs to ensure adequate disclosure of the attributes explored in this study. In addition, in order to evaluate the Shariah disclosure practices of Islamic banks, regulator is also recommended to adopt ShDI. Islamic banks' stakeholders are also recommended to ShDI before making their business decisions toward any Islamic bank. In order to achieve a robust findings, it is recommended to add more mandatory, voluntary, and standard attributes concerning Shariah disclosure and reporting. 


\section{References}

Abdullah, B. H. (2014). An exploratory examination into the relationship between corporate governance and risk management in Islamic banks: Disclosure and survey analysis (Doctoral thesis, Durham University, Durham, United Kingdom). Retrieved from http://etheses.dur.ac.uk/10817/

Abdullah, W. A. W., Percy, M., \& Stewart, J. (2013). Shari'ah disclosures in Malaysian and Indonesian Islamic banks:The Shari'ah governance system. Journal of Islamic Accounting and Business Research, 4(2), 100-131. https://doi.org/10.1108/JIABR-10-2012-0063

Abdullah, W. A. W., Percy, M., \& Stewart, J. (2015). Determinants of voluntary corporate governance disclosure: Evidence from Islamic banks in the Southeast Asian and the Gulf Cooperation Council regions. Journal of Contemporary Accounting and Economics, 11(3), 262-279. https://doi.org/10.1016/j. jcae.2015.10.001

Abdullah, W., \& Syariati, A. (2016). Islamic bank as bank of ethics. Journal of Research in Business and Management, 4(4), 1-4. Retrieved from https://www.researchgate.net/publication/325140019_Islamic_Bank_As_Bank_of_Ethics

Abuhmaira, M. A. (2006). The impact of "AAOIFI" standards on the financial reporting of Islamic banks: Evidence from Bahrain (Doctoral thesis). Available from British Library e-theses database. (Order No. 429476)

Ahmed, A., \& El-belihy, A. (2017). An investigation of the disclosure of corporate social responsibility in UK Islamic banks. Academy of Accounting and Financial Studies Journal, 21(3), 1-31.

Al-baluchi, A. E. A. (2006). The impact of AAOIFI standards and other bank characteristics on the level of vol untary disclosure in the annual reports of Islamic banks (Doctoral thesis, University of Surrey, Guildford, United Kingdom). Retrieved from http://epubs.surrey.ac.uk/801/

Al-Mehmadi, F. B. S. B. S. (2004). The external reporting needs of investors in Islamic banks in Saudi Arabia: An exploratory study of full disclosure (Doctoral thesis). Available from British Library e-theses database. (Order No. 496402)

Albassam, W. M., \& Ntim, C. G. (2017). The effect of Islamic values on voluntary corporate governance disclosure: The case of Saudi-listed firms. Journal of Islamic Accounting and Business Research, 8(2), 182-202. https://doi.org/10.1108/JIABR-09-2015-0046

Amran, A., Fauzi, H., Purwanto, Y., Darus, F., Yusoff, H., Zain, M. M.,... Nejati, M. (2017). Social responsibility disclosure in Islamic banks: A comparative study of Indonesia and Malaysia. Journal of Financial Reporting and Accounting, 15(1), 99-115. https://doi.org/10.1108/JFRA-01-2015-0016

Askari, H., Iqbal, Z., Krichenne, N., \& Mirakhor, A. (2010). The stability of islamic Finance: Creating a resilient financial environment for a secure future. Singapore: John Wiley \& Sons.

Asutay, M., \& Harningtyas, A. F. (2015). Developing Maqasid al-Shari'ah index to evaluate social performance of Islamic banks: A conceptual and empirical attempt. International Journal of Islamic 
Economics and Finance Studies, 1(1), 5-64. Retrieved from https://dergipark.org.tr/en/pub/ijisef/ issue $/ 29332 / 313846$

Belal, A. R., Abdelsalam, O., \& Nizamee, S. S. (2015). Ethical reporting in Islami Bank Bangladesh Limited (1983-2010). Journal of Business Ethics, 129(4), 769-784. https://doi.org/10.1007/s10551014-2133-8

BIancone, P. P., Shakhatreh, M. Z., \& Radwan, M. (2016). Operational risk management disclosure in Islamic banks. In V. Cantino, P. De Vincentiis, \& G. Racca (Eds.), Risk management: Perspectives and open issues (pp. 62-78). Italy: McGraw-Hill Education.

Darmadi, S. (2013). Corporate governance disclosure in the annual report: An exploratory study on Indonesian Islamic banks. Humanomics, 29(1), 4-23. https://doi.org/10.1108/08288661311299295

El-halaby, S., Hussainey, K., \& El-Sood, H. A. (2015). The determinants of the disclosure level of Sharia compliance in Islamic Bank. In 10th International Conference on Islamic Economics and Finance. Doha, Qatar: Islamic Research and Training Institute.

Elamer, A. A., Ntim, C. G., \& Abdou, H. A. (2017). Islamic governance, national governance, and bank risk management and disclosure in MENA countries. Business $\mathcal{E}$ Society, 59(5), 914-955. https:// doi.org/10.1177/0007650317746108

Gilani, H. (2015). Exploring the ethical aspects of Islamic banking. International Journal of Islamic and Middle Eastern Finance and Management, 8(1), 85-98. https://doi.org/10.1108/IMEFM-09-2012-0087

Grais, W., \& Pellegrini, M. (2006). Corporate governance in institutions offering Islamic financial services issues and options (World Bank Policy Research Working Paper No. 4052). Available at SSRN: https:// ssrn.com/abstract $=940709$

Grassa, R. (2013). Sharilah governance system in Islamic financial institutions: New issues and challenges. Arab Law Quarterly, 27(2), 171-187. https://doi.org/10.1163/15730255-12341254

Grassa, R., Chakroun, R., \& Hussainey, K. (2018). Corporate governance and Islamic banks ' products and services disclosure. Accounting Research Journal, 31(1), 75-89. https://doi.org/10.1108/ARJ09-2016-0109

Hamid, W., Ubud, S., Djumahir, \& Siti, A. (2016). Trade principles and Sharia-Adhehence banking performance analysis by employing maqasid Islamic Shariah index approach: Study on Indonesian Sharia bank. Russian Journal of Agricultural and Socio-Economic Sciences, 11(59), 66-74. https://doi. org/10.18551/rjoas.2016-11.09

Haniffa, R., \& Hudaib, M. (2007). Exploring the ethical identity of Islamic banks via communication in annual reports. Journal of Business Ethics, 76(1), 97-116. https://doi.org/10.1007/s10551-006-9272-5

Harun, M. S. Bin. (2016). The impact of corporate governance and its consequences on CSR disclosure: Empirical evidence from Islamic banks in GCC countries (Doctoral thesis, University of Plymouth, Plymouth, United Kingdom). Retrieved from http://hdl.handle.net/10026.1/6608 
Hasan, Z. (2011). A survey on Shari'ah governance practices in Malaysia, GCC countries and the UK: Critical appraisal. International Journal of Islamic and Middle Eastern Finance and Management, 4(1), 30-51. https://doi.org/10.1108/17538391111122195

Hasan, Z. (2012). Shari'ah governance in Islamic banks. Edinburgh: Edinburgh University Press.

Hassan, A., \& Syafri Harahap, S. (2010). Exploring corporate social responsibility disclosure: The case of Islamic banks. International Journal of Islamic and Middle Eastern Finance and Management, 3(3), 203-227. https://doi.org/10.1108/17538391011072417

Herwiyanti, E., MA, A. S. W., \& Rosada, A. (2005). Analysis of factors influencing the Islamic corporate governance disclosure index of Islamic banks in Asia. International Journal of Humanities and Management Sciences, 3(4), 192-197.

Islamic Banking Department, State Bank of Pakistan. (2018). Shari'ah governance framework for Islamic banking institutions (updated till June 2018). Retrieved from http://www.sbp.org.pk/ibd/2018/C1.htm

Ibrahim, S. H. B. M., Wirman, A., Alrazi, B., \& Pramono, S. (2004). Alternative disclosure $\mathcal{E}$ performance measures for Islamic banks. In Second Conference on Administrative Science: Meeting the Challenges of the Globalization Age, King Fahd University of Petroleum and Minerals, Dahran, Saud Arabia (pp. 19-21).

Inten, M., \& Devi, F. (2017). Islamic social reporting in Islamic banking: Stakeholders theory perspective. SHS Web of Conferences. https://doi.org/10.1051/shsconf/20173412001

Ismail, M., Jan, S., \& Ullah, K. (2018). Determinants of Shari'ah disclosure in Islamic banking institutions. Abasyn University Journal of Social Sciences, 11.

Jan, S., \& Asutay, M. (2019). A model of Islamic development: An approach in Islamic moral economy. Cheltenham: Edward Elgar.

Jan, S., Khan, Z., \& Ullah, K. (2018). Institutionalising justice in Islamic finance. Journal of Islamic Banking and Finance, 14(1), 205-216.

Jan, S., Ullah, K, \& Asutay, M.(2015). Knowledge, work, and social welfare as Islamic socio-economic development goals. Journal of Islamic Banking and Finance, 32(3), 11-21.

Jan, S., Ullah, K., \& Asutay, M. (2016). Islamic perspective of development: Maqasid Al Shariah, Islamic moral economy, and socio-economic development goals. In I. A. Ghafar, A. S. Syed, \& H. L. B. B. Mameed (Eds), Policy discussion on Maqasid Al Shariah for socio economic development. (pp. 45-58). Penerbit kuis.

Kamla, R., \& Rammal, H. G. (2013). Social reporting by Islamic banks: Does social justice matter? Accounting, Auditing $\mathcal{E}$ Accountability Journal, 26(6), 911-945. https://doi.org/10.1108/AAAJ-03-2013-1268

Maali, B., Casson, P., \& Napier, C. (2006). Social reporting by Islamic banks. ABACUS A Journal of Accounting, Finance, and Business Studies, 42(2), 266-289. https://doi.org/10.1111/j.1467-6281.2006.00200.x 
Masruki, R., Hanefah, M. M., \& Wahab, N. A. (2018). Shariah Supervisory Board (SSB) and performance of Islamic banks in Malaysia. International Journal of Engineering $\mathcal{E}$ Technology, 7(3.25), 710-714. Retrieved from https://www.sciencepubco.com/index.php/ijet/article/view/17831

Noordin, N. H., Kassim, S., Prabangasta, D., \& Hayeeyahya, N. (2015). Does composition of Shariah committee influence Shariah governance disclosure? Evidence from Islamic banks in Malaysia. IIUM Institute of Islamic Banking and Finance, Malaysia, (July), 31.

Obid, S. N. S., \& Hajj, A. F. (2011). Bank ethical disclosure level: Malaysian Islamics bank. Asia Pacific Journal of Accounting and Finance, 1(2), 199-210.

Othman, R., \& Thani, A. M. (2010). Islamic social reporting of listed companies in Malaysia. International Business $\mathcal{E}$ Economics Research Journal, 9(4), 135-144. https://doi.org/10.19030/iber.v9i4.561

Othman, R., Thani, A. M., \& Ghani, E. K. (2009). Determinants of Islamic social reporting among top Shariah approved companies in Bursa Malaysia. Research Journal of Internatıonal Studies, 12(12), 4-20.

Ousama, A. A., \& Fatima, A. H. (2010). Voluntary disclosure by Shariah approved companies: An exploratory study. Journal of Financial Reporting and Accounting, 8(1), 35-45. https://doi. org/10.1108/19852511011055943

Platonova, E. (2014). Comparative analysis of CSR disclosure and its impact on financial performance in the GCC Islamic banks (Doctoral thesis, Durham University, Durham, United Kingdom). Retrieved from http://etheses.dur.ac.uk/10726/

Raharja, S. (2011). An examination of social disclosure by Islamic banks in Indonesia. Paper presented at the IIUM International Accounting Conference V (INTAC V), Pan Pacific Klia, Malaysia. Retrieved from http://eprints.undip.ac.id/36114/

Rahman, R. A., Danbatta, B. L., \& Saimi, N. S. B. (2014). Corporate ethical identity disclosures: The perceived, the publicized and the applied in Islamic banks. International Journal of Trade, Economics and Finance, 5(2), 199-203. https://doi.org/10.7763/IJTEF.2014.V5.371

Rashid, M., \& Hassan, M. K. (2014). Market value of Islamic banks and ethical identity. American Journal of Islamic Social Sciences, 31(2), 43-79.

Said, R., Abd Samad, K., Mohd Sidek, N. Z., Ilias, N. F., \& Omar, N. (2018). Corporate social responsibility disclosure index of Malaysian Shariah - compliant companies. International Journal of Ethics and Systems, 34(1), 55-69. https://doi.org/10.1108/IJOES-09-2016-0068

Setyawan, H., \& Permatasari, D. (2017). Corporate governance disclosure practices: Evidence from Indonesian Islamic banks. Paper presented at_Seminar Nasional Hasil Penelitian dan Pengabdian Masyarakat UNIMUS 2017, Semarang, Indonesia.

Srairi, S. (2015). Corporate governance disclosure practices and performance of Islamic banks in GCC countries. Journal of Islamic Finance, 4(2), 1-17. 
Sugianto, \& Harapan, N. (2017). The Integration of Disclosure of Islamic Social Reporting (ISR) in Islamic Bank Financial Statements. In M. Y. Jaaffar, A. A. Sani, \& A. Muhammad (Eds.), The 2016 4th International Conference on Governance and Accountability (pp. 133-146). EDP Sciences. https:// doi.org/10.1051/shsconf/20173600011

Triyuwono, I., \& Kamayanti, A. (2014). Islamic values Islamic bank underlying performance assessment. Research Journal of Finance and Accounting, 5(24), 106-113.

Ullah, K. (2014). Adaptable service-system design: An analysis of Shariah finance in Pakistan (Doctoral thesis, Brunel University, London, United Kingdom). Retrieved from https://bura.brunel.ac.uk/ handle/2438/8281

Zafar, M. B., \& Sulaiman, A. A. (2018). Corporate social responsibility and Islamic banks : A systematic literature review. Management Review Quarterly, 69, 159-206. https://doi.org/10.1007/s11301-0180150-x

Zainuddin, Z., \& Nordin, N. (2016). Addressing governance issue in Islamic Real Estate Investment (I-REITs): A case study for OIC country-Malaysia. International Journal of Islamic Business, 1(1), 60-75.

Zubairu, U. M., Sakariyau, O. B., \& Dauda, C. K. (2012). Evaluation of social reporting practices of Islamic banks in Saudi Arabia. Electronic Journal of Business Ethics and Organizational Studies, 17(1), 41-50. 